\title{
Studies on meropenem and cefixime metal ion complexes for antibacterial activity
}

\author{
Milind J. Umekar ${ }^{1}$, Radheshyam T. Lohiya ${ }^{1}$, Krishna R. Gupta ${ }^{1}$, Nandkishore R. Kotagale ${ }^{2}$ and Neha S. Raut ${ }^{*}$
}

\begin{abstract}
Background: The metal ion complexes of meropenem and cefixime with cadmium, silver, palladium, zinc, nickel, cobalt and copper were synthesized and characterized by UV, FTIR and $H^{1-N M R ~ s p e c t r o p h o t o m e t r y . ~ T h e ~ a n t i b a c t e r i a l ~}$ effects of the complexes were studied using cup and plate method against S. aureus, B. subtilis, E. coli, P. aeruginosa and K. pneumoniae for normal and resistant strains of bacteria. The minimum inhibitory concentration of the metal ion complexes was determined by broth dilution method.

Results: UV spectroscopic studies suggested that meropenem ligand form complex with different metal ions and FTIR spectrum confirmed the proposed structure. Similarly, UV spectrum of cefixime metal ion complexes at $\lambda_{\max }$ 202-295 nm and meropenem metal ion complexes at $\lambda_{\max } 249-304 \mathrm{~nm}$ was observed in all the complexes. FTIR peaks for a proposed structure were observed in all the meropenem and cefixime metal ion, indicating the formation of complexes, and retained the functional groups of drugs. Meropenem as well as cefixime metal ion complexes exhibited more antibacterial activity against all the selected bacterial strains. Specifically, the lowest minimum inhibitory concentration against $P$. aeruginosa and $K$. pneumoniae was observed to be 100 and $150 \mu \mathrm{g} / \mathrm{ml}$, respectively.

Conclusion: The present study concluded that the meropenem and cefixime metal complexes can exhibit the better treatment than individual drug on normal as well as resistant bacteria.
\end{abstract}

Keywords: Meropenem, Cefixime, Metal ion complex, Antibacterial, MIC, Resistance

\section{Background}

Metal ion exhibits antibacterial activity against most of the bacteria. Currently, complexes of antibiotics with metal ions focus the attention for new drugs as well as those endeavoring to increase the activity of antibiotics in use. Therefore, the role of antibiotic-metal complexes (AMC) in the field of pharmaceutical research has been constantly expanding. Moreover, it is necessary for the present situation to search for new, more effective and more broadly acting drugs due to an alarming increase in the growing number of drug-resistant bacteria [1]. This growing interest and research activities in the search for new combinations of metal ions with various classes

\footnotetext{
*Correspondence: rautneha123@gmail.com

1 Smt. Kishoritai Bhoyar College of Pharmacy, Kamptee, Nagpur,

Maharashtra 441002, India

Full list of author information is available at the end of the article
}

of antibiotics and other pharmaceuticals are currently observed. For overcoming the effects of resistant microorganisms such complexes have been intensively studied in recent years [2-5]. As reported in the literature, the use of metalloantibiotics, nanoparticles with metal ions, green nanoparticles and similar type of novel formulations allows for reduction of dose introduced into the body, enhancement of bioavailability and benefiting from the pharmaceutical effects of both ligand antibiotics and metal ions [6].

The interaction of metal ions with drugs and proteins, green-synthesized nanoparticles and metal ions has been recognized internationally as an important area for research. Metals existing in the nature due to their variable oxidation states, number and types of coordinated ligands and coordinative geometry after complexation can provide variety of properties, whereas the ligands can not only control the reactivity of the metal, but also play 
critical roles in determining the nature of interactions involved in the recognition of biological target sites, such as DNA, enzymes and protein receptors. These variables provide enormous potential diversity for the design of metallodrugs. Synthesized metal complexes might prove to have altered therapeutic activity or may have toxic effects [7].

The appearance of resistant bacteria was found to reduce the efficiency of antimicrobial therapies with the current antibiotics, thereby increasing the need for more efficient drugs for the treatment of infections. Several studies have demonstrated an increase in antimicrobial activity following the interaction of several compounds with metal ions. The interaction of metal ions with organic ligands shows better antimicrobial activity compared to free ligands (not coordinated), and as such, it justifies the investigation of new drugs with unknown mechanism of action against pathogenic bacteria. The use of these new compounds is likely to have great potential against pathogenic bacteria; nonetheless, the need for new methodologies of evaluation of antimicrobial activity cannot be relegated to the background [8].

The potential for further development of metal-based drugs and treatments as antimicrobial agents is enormous and has great importance with the evolution of drug-resistant bacteria. Numerous clinical trials for the usage of metals in therapeutics have been carried out worldwide for assessing metal-based drug's efficacy in a wide diversity of human problems proving it to be an antibiotic alternative at a convenient dosage [9]. Therefore, the present study was carried out on synthesis and evaluation of meropenem and cefixime metal ion complexes for antibacterial activity.

Resistance mechanisms are the result of altered physiological proteins and targets on the cell surface. The major mechanisms responsible for multidrug resistance (MDR) include the alteration of targets, generation of inactivated enzymes or passivated enzymes, use of active efflux pump systems, presentation of obstacles to antibiotic permeation, formation of biofilms, emergence and elimination of a specific protein, induction of an antagonist through metabolic pathways and increased production of a competitive inhibitor counteracting the antibiotic. Concurrent with the increased incidence of bacterial resistance to antibiotics, researchers are directed toward alternative therapies, including traditional plant-based medicines, bacteriophage therapies, metal ion drug complexes and combinational therapies [10].

Meropenem is (4R,5S,6S)-3-[(3S,5S)-5-(dimethyl-
carbamoyl)

1-hydroxyethyl]-4-methyl-7-oxo-1-azabicyclo[3.2.0] hept-2-ene-2-carboxylic acid a parenteral carbapenem with wide spectrum antibacterial activity against gram-positive and gram-negative microorganisms [11]. Cefixime is 7-2(2-(amino-4-thiazolyl)-2(carboxymethoxyimino) acetamido) -3-vinyl-cephem4-carboxylic acid a thirdgeneration semisynthetic cephalosporin antibiotics broad spectrum more active against gram-negative strains and less active against gram-positive strains, whereas the prolonged use of these broad-spectrum antibiotics is particularly worrying as it promotes the spread of multidrug-resistant, difficult-to-treat pathogens $[12,13]$.

The present research work has been carried out with the objective to synthesize, characterize and evaluate the antibacterial effect of meropenem and cefixime metal ion complexes as these are repetitively prescribed drug in the treatment of respiratory diseases.

\section{Methods}

Meropenem trihydrate was gifted by Aurobindo Pharma Limited, and cefixime trihydrate was gifted by Zim Laboratories. Metal salts such as cadmium chloride $\left[\mathrm{CdCl}_{2}(\mathrm{II})\right]$, silver chloride $\left[\mathrm{AgCl}_{2}(\mathrm{II})\right]$, palladium chloride $\left[\mathrm{PdCl}_{2}(\mathrm{II})\right]$, zinc chloride $\left[\mathrm{ZnCl}_{2}(\mathrm{II})\right]$, nickel chloride $\left[\mathrm{NiCl}_{2}(\mathrm{II})\right]$, cobalt chloride $\left[\mathrm{CoCl}_{2}(\mathrm{II})\right]$ and copper chloride $\left[\mathrm{CuCl}_{2}(\mathrm{II})\right]$, other solvents and reagent of analytical grade were purchased from Lobachemie and Merck PVT LTD. FTIR spectra recorded on Prestige-21 FTIR instrument were FTIR 8004s. ${ }^{1} \mathrm{H}-\mathrm{NMR}$ instruments were Bruker AMX $400 \mathrm{MHz}$. Chemical shifts were reported in ppm using tetramethylsilane (TMS) as an internal standard. UV-visible spectra were recorded on Jasco UV spectrophotometer.

\section{Synthesis of antibacterial drug and cadmium metal complexes}

Meropenem-cadmium (Mero-Cd) complex was prepared by dissolving $1 \mathrm{mmol}(0.1833 \mathrm{~g}) \mathrm{CdCl}_{2}$ in absolute hot ethanol $(10 \mathrm{ml})$. To this solution, $2 \mathrm{mmol}(0.7669 \mathrm{~g})$ of meropenem solution in ethanol was added [13]. For cefixime-cadmium (Cef-Cd) complex, $1 \mathrm{mmol}(0.1833 \mathrm{~g})$ $\mathrm{CdCl}_{2}$ was dissolved in absolute hot ethanol $(10 \mathrm{ml})$. Further, $2 \mathrm{mmol}(0.9069 \mathrm{~g})$ of cefixime solution in ethanol was added. Both the mixtures were stirred magnetically and separately at room temperature for a week. The precipitated complex was separated, washed with ethanol and dried [14].

\section{Synthesis of antibacterial drug and silver metal complexes} Meropenem-silver (Mero-Ag) complex was prepared using $1 \mathrm{mmol}(0.1433 \mathrm{~g}) \mathrm{AgCl}_{2}$ which was dissolved in absolute hot ethanol $(10 \mathrm{ml})$; to this solution, $2 \mathrm{mmol}$ $(0.7669 \mathrm{~g})$ of meropenem solution in ethanol was added. Separately, cefixime-silver (Cef-Ag) complex, $1 \mathrm{mmol}$ $(0.1433 \mathrm{~g}) \mathrm{AgCl}_{2}$ was dissolved in $10 \mathrm{ml}$ of absolute hot ethanol and $2 \mathrm{mmol}(0.9069 \mathrm{~g})$ of cefixime solution in 
ethanol was added. The mixture was stirred magnetically at room temperature for a week. The precipitated complex was filtered, washed with ethanol and dried [15].

\section{Synthesis of antibacterial drug and palladium metal complexes}

Meropenem-palladium (Mero-Pd) complex was prepared by dissolving $1 \mathrm{mmol}(0.1773 \mathrm{~g}) \mathrm{PdCl}_{2}$ in $10 \mathrm{ml}$ of absolute hot ethanol, and $2 \mathrm{mmol}(0.7669 \mathrm{~g})$ of meropenem solution in ethanol was added. For cefixime-palladium (Cef-Pd) complex, $1 \mathrm{mmol}(0.1773 \mathrm{~g}) \mathrm{PdCl}_{2}$ was dissolved in absolute hot ethanol $(10 \mathrm{ml})$. To this solution $2 \mathrm{mmol}$ $(0.9069 \mathrm{~g})$ of cefixime solution in ethanol was added. The mixture was stirred magnetically at room temperature for a week. The precipitated complex was filtered, washed with ethanol and dried [16].

\section{Synthesis of antibacterial drug and zinc metal complexes} For meropenem-zinc (Mero-Zn) complex, $1 \mathrm{mmol}$ $(0.1362 \mathrm{~g}) \mathrm{ZnCl}_{2}$ was dissolved in absolute hot ethanol $(10 \mathrm{ml})$. To this solution $2 \mathrm{mmol}(0.7669 \mathrm{~g})$ of meropenem solution in ethanol was added. Similarly, cefixime-zinc (Cef-Zn) complex was prepared by solubilizing $1 \mathrm{mmol}$ $(0.1362 \mathrm{~g}) \mathrm{ZnCl}_{2}$ in $10 \mathrm{ml}$ of absolute hot ethanol, and to this solution, $2 \mathrm{mmol}(0.9069 \mathrm{~g})$ of cefixime solution in ethanol was added. The mixture was stirred magnetically at room temperature for a week. The precipitated complex was filtered, washed with ethanol and dried [17].

\section{Synthesis of antibacterial drug and nickel metal complexes} Meropenem-nickel (Mero-Ni) complex prepared using $1 \mathrm{mmol}(0.1295 \mathrm{~g}) \mathrm{NiCl}_{2}$ was dissolved in absolute hot ethanol $(10 \mathrm{ml})$. To this solution $2 \mathrm{mmol}(0.7669 \mathrm{~g})$ of meropenem solution in ethanol was added. Likewise, cefixime-nickel (Cef-Ni) complex, $1 \mathrm{mmol}(0.1295 \mathrm{~g})$ $\mathrm{NiCl}_{2}$ was dissolved in absolute hot ethanol $(10 \mathrm{ml})$. To this solution $2 \mathrm{mmol}(0.9069 \mathrm{~g})$ of cefixime solution in ethanol was added. The mixture was stirred magnetically at room temperature for a week. The precipitated complex was filtered, washed with ethanol and dried [16].

\section{Synthesis of meropenem and cobalt metal complexes}

Meropenem-cobalt (Mero-Co) complex was prepared by dissolving $1 \mathrm{mmol}(0.1298 \mathrm{~g}) \mathrm{CoCl}_{2}$ in absolute hot etha$\mathrm{nol}(10 \mathrm{ml})$. To this solution $2 \mathrm{mmol}(0.9069 \mathrm{~g})$ of meropenem solution in ethanol was added. The mixture was stirred magnetically at room temperature for a week. The precipitated complex was filtered, washed with ethanol and dried $[13,18]$.

\section{Synthesis of cefixime and copper metal ion complexes} For cefixime-copper (Cef-Cu) complex, $1 \mathrm{mmol}$ $(0.1344 \mathrm{~g}) \mathrm{CuCl}_{2}$ was dissolved in absolute hot ethanol
$(10 \mathrm{ml})$. To this solution $2 \mathrm{mmol}(0.9069 \mathrm{~g})$ of cefixime solution in ethanol was added. The mixture was stirred magnetically at room temperature for a week. The precipitated complex was filtered, washed with ethanol and dried.

\section{Characterization of synthesized complexes Organoleptic properties}

The synthesized complexes of meropenem and cefixime with $\mathrm{Cd}, \mathrm{Ag}, \mathrm{Pd}, \mathrm{Zn}, \mathrm{Ni}$, Co and $\mathrm{Cu}$ were observed for their color (appearance) and percent yield.

\section{Solubility study}

The solubility of synthesized complexes were determined in different solvents such as water, $5 \%$ sodium hydroxide, $5 \%$ hydrochloric acid, conc. sulfuric acid, methanol, diethyl ether.

\section{UV spectrophotometric analysis}

The solution of the meropenem, cefixime and its synthesized complexes with metal ions were prepared in methanol $(10 \mu \mathrm{g} / \mathrm{ml})$ and was scanned in the region of 200-600 nm using 630 Jasco UV spectrophotometer.

\section{FTIR analysis}

The IR spectra of the meropenem, cefixime and its synthesized complexes with metal ions were taken using $\mathrm{KBr}$ disks. All the compounds were scanned in the region of $4000-600 \mathrm{~cm}^{-1}$.

\section{NMR spectral analysis}

The ${ }^{1} \mathrm{H}$-NMR spectra of some selected synthesized complexes with meropenem and cefixime were recorded on BrukerAvance300 using tetra methylsilane (TMS) as internal standard, and DMSO was used as solvent. The NMR spectroscopy was done by STIC Kochi University, Kochi, Kerala. The chemical shifts are expressed in $\delta$ (ppm).

\section{Antibacterial activity}

The meropenem, cefixime and its synthesized complexes with metal ions were tested against bacterial strains; gram-positive bacteria Staphylococcus aureus, Bacillus subtilis and gram-negative bacteria Escherichia coli, Klebsiella pneumoniae, Pseudomonas aeruginosa [26, 27]. Broth culture $(0.75 \mathrm{ml})$ of individual strain was added in nutrient agar medium at $45{ }^{\circ} \mathrm{C}$, mixed well and then poured into a sterile Petri plate. The media were allowed to solidify, and $6 \mathrm{~mm}$ wells were drug with a sterile metallic borer. Then a DMSO solution of test sample $(100 \mu \mathrm{l})$ at $1 \mathrm{mg} / \mathrm{ml}$ was added to the respective wells. DMSO served as negative control, and the standard antibacterial drug $(100 \mu \mathrm{g} / \mathrm{ml})$ was used as positive control. Duplicate 
plates of each bacterial strain were prepared which was incubated aerobically at $37^{\circ} \mathrm{C}$ for $24 \mathrm{~h}$. The activity was determined by measuring the diameter of zone showing complete inhibition $(\mathrm{mm})$. The growth inhibition was calculated with reference to the positive control $[19,20]$.

\section{Minimum inhibitory concentration determination}

The minimum inhibitory concentrations (MIC)s of selected compounds, which showed significant activity against selected bacterial strains, were determined using the broth dilution method by preparing tube containing different concentration and according to standard protocol. MIC was the lowest concentration of an antimicrobial compound at which the inhibition of growth occurred $[20,21]$.

\section{Results}

Physiochemical characterization of synthesized complexes The initial nature of meropenem and cefixime was white and amorphous in nature, whereas the synthesized complexes Mero-Cd, Mero-Ag, Mero-Pd, Mero-Zn, Mero-Ni and Mero-Co were changing its appearance to yellowish orange, gray powder, gray powder, brown powder, greenish yellow powder and gray powder, and the percent yield was found to be 44.52, 81.51, 32.24, 32.12, 49.30 and $21.95 \%$, respectively. Similarly, the Cef-Cd, Cef-Ag, Cef$\mathrm{Pd}, \mathrm{Cef}-\mathrm{Zn}, \mathrm{Cef}-\mathrm{Ni}$ and $\mathrm{Cef}-\mathrm{Cu}$ were pale orange powder, gray color powder, dark brown powder, orange crystalline solid and yellowish-brown crystals nature with percent yield 26.98, 79.46, 83.08, 45.36, 39.69 and 75.72\%, respectively.

The solubility of synthesized complexes were determined in different solvents such as water, $5 \%$ sodium hydroxide, $5 \%$ hydrochloric acid, conc. sulfuric acid, methanol, diethyl ether. The solubility of complexes was found to be more in 5\% sodium hydroxide and conc. sulfuric acid. Whereas the solubility in water, $5 \%$ hydrochloric acid and ether was observed partial or insoluble indicating binding of metal ion with drug may decreases solubility in water.

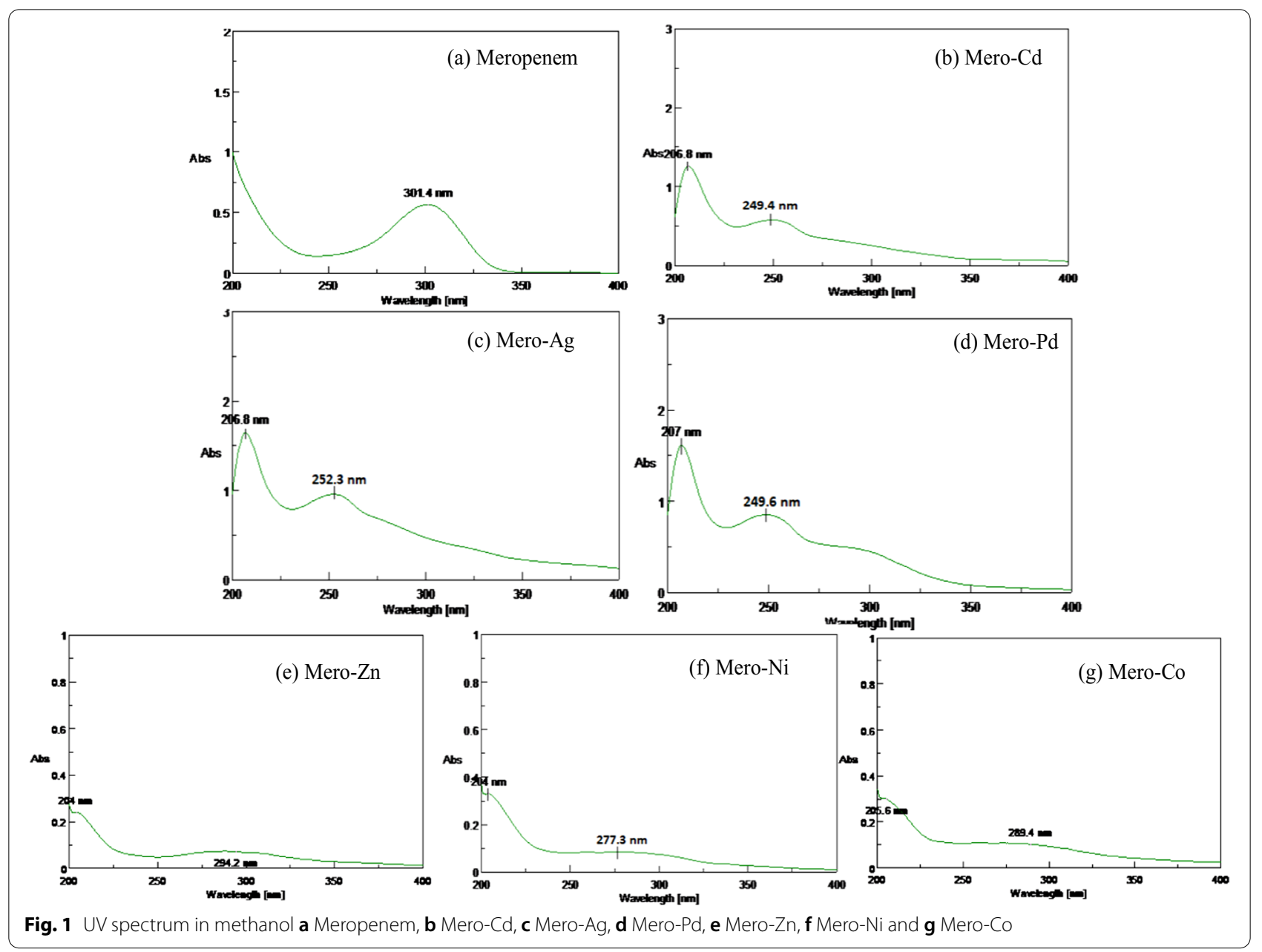




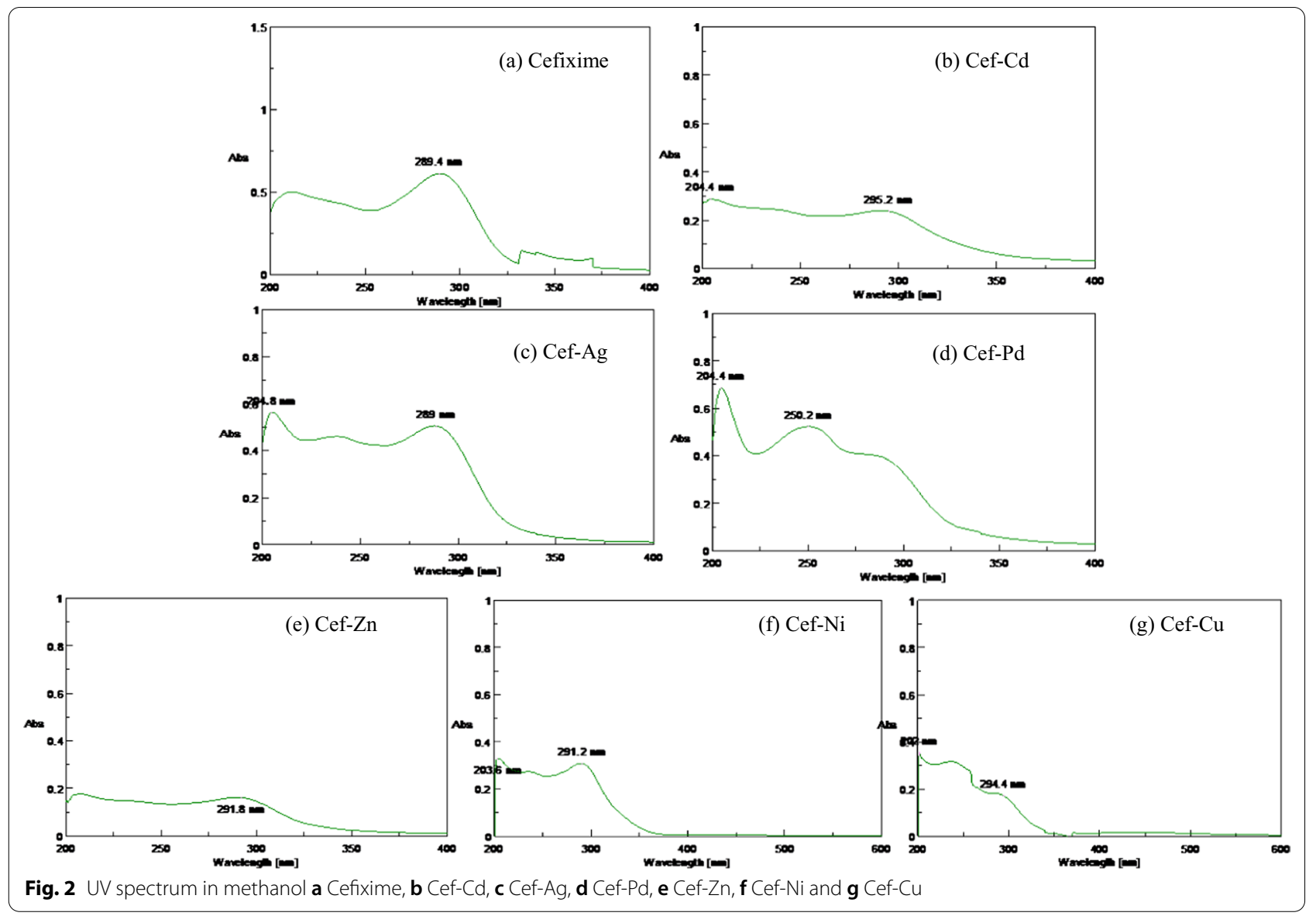

UV spectrophotometric analysis

The UV spectrum of meropenem in methanol has shown highest absorbance at $301.2 \mathrm{~nm}$ which resembles to the $\lambda_{\max }$ of meropenem in the range of $300-310 \mathrm{~nm}$ as mentioned in the literature [22]. The UV absorption spectra of meropenem metal ion complexes showed characteristic peaks from 250 to $295 \mathrm{~nm}$, indicating that there were the presence of $n-\pi^{*}$ transition and

Table 1 FTIR peaks of meropenem, cefixime and its synthesized complexes

\begin{tabular}{|c|c|c|c|c|c|c|c|}
\hline \multirow{2}{*}{$\begin{array}{l}\text { Functional group } \\
\text { Stretching }\end{array}$} & \multicolumn{7}{|c|}{ Wave number in $\mathrm{cm}^{-1}$} \\
\hline & Mero & Mero-Cd & Mero-Ag & Mero-Pd & Mero-Zn & Mero-Ni & Mero-Co \\
\hline $\mathrm{N}-\mathrm{H}$ & 3348 & 3427 & 3427 & 3376 & 3354 & 3346 & - \\
\hline Aliphatic $\mathrm{C}-\mathrm{H}$ & 2935 & 2968 & 2936 & 2970 & 2977 & 2912 & - \\
\hline$C=C$ & 985 & 1645 & 1645 & 1634 & 1621 & 1606 & 2977 \\
\hline $\mathrm{C}-\mathrm{O}$ & 1141 & 1149 & 1149 & 1154 & 1174 & 1143 & 1620 \\
\hline Stretching & Cef & Cef-Pd & Cef-Ag & Cef-Zn & Cef-Ni & Cef-Cu & Cef-Cd \\
\hline$-\mathrm{OH}$ & 3580 & - & - & - & - & - & - \\
\hline$C=O$ & 1770 & 1720 & $1720-1780$ & - & - & $1720-1740$ & 1760 \\
\hline $\mathrm{N}-\mathrm{O}$ & 1541.12 & 1540 & $1520-1580$ & $1540-1560$ & $1520-1560$ & 1520 & 1520 \\
\hline $\mathrm{C}-\mathrm{N}$ & 1338.60 & 1340 & $1340-1380$ & 1360 & - & $1360-1400$ & 1320 \\
\hline $\mathrm{C}-\mathrm{O}$ & 1095.57 & 1080 & 1100 & 1080 & 1080 & 1064.71 & 1040 \\
\hline$(\mathrm{C}=\mathrm{O})-\mathrm{NH}$ & 1670 & 1620 & 1660 & 1620 & 1660 & 1681.93 & 1620 \\
\hline$C-S$ & $690-685$ & 660 & 680 & 660 & 660 & 620 & 660 \\
\hline
\end{tabular}



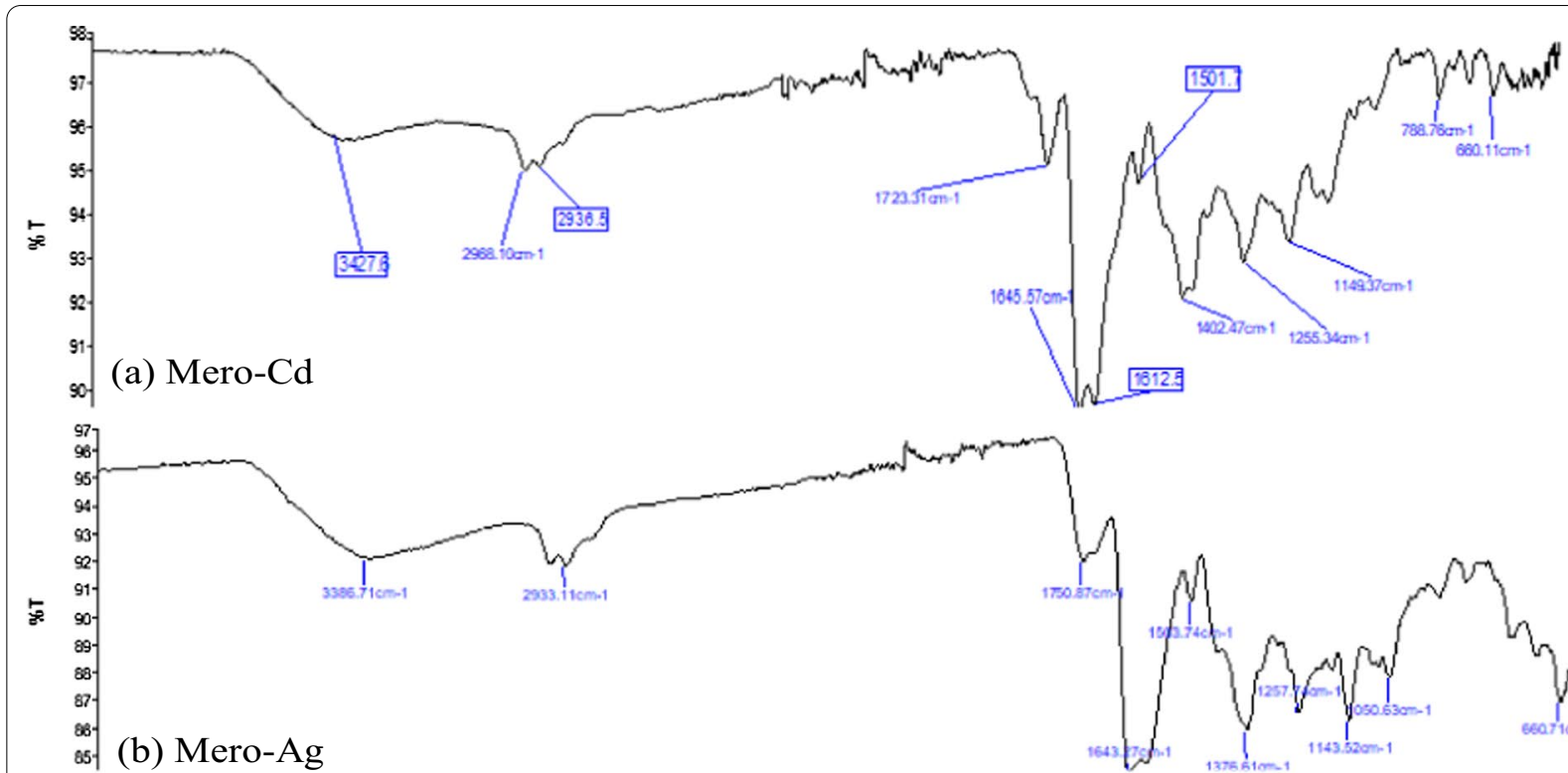

(b) Mero-Ag
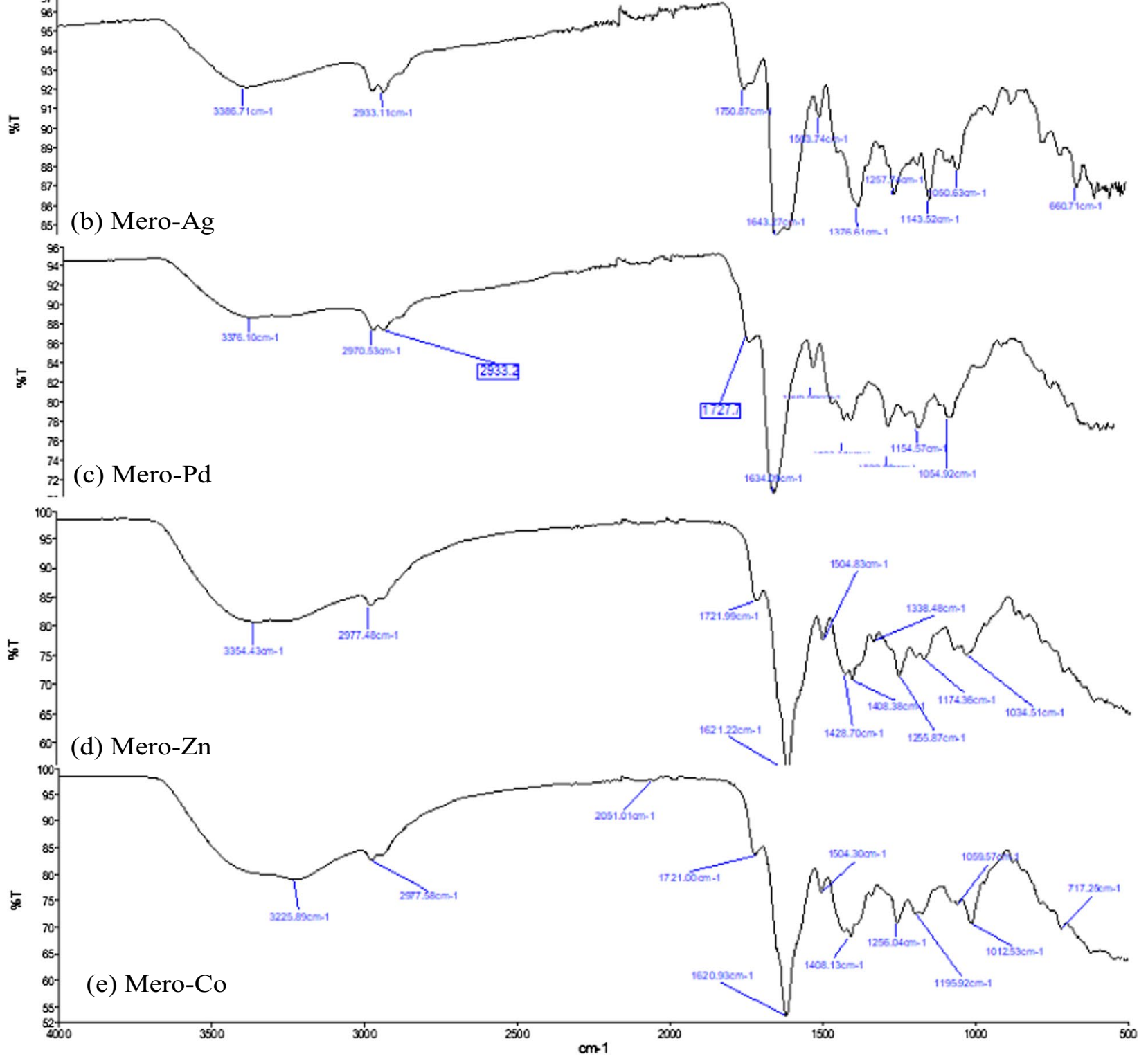

Fig. 3 FTIR spectrum of a Mero-Cd, b Mero-Ag, c Mero-Pd, d Mero-Zn and e Mero-Co

$\pi-\pi^{*}$ transitions in the compounds due to carbonyl group $[22,23]$.
As shown in Figs. 1 and 2, meropenem metal ion complexes exhibited changes in UV spectrum such as decrease in absorbance at $\lambda_{\max }$ of meropenem or 


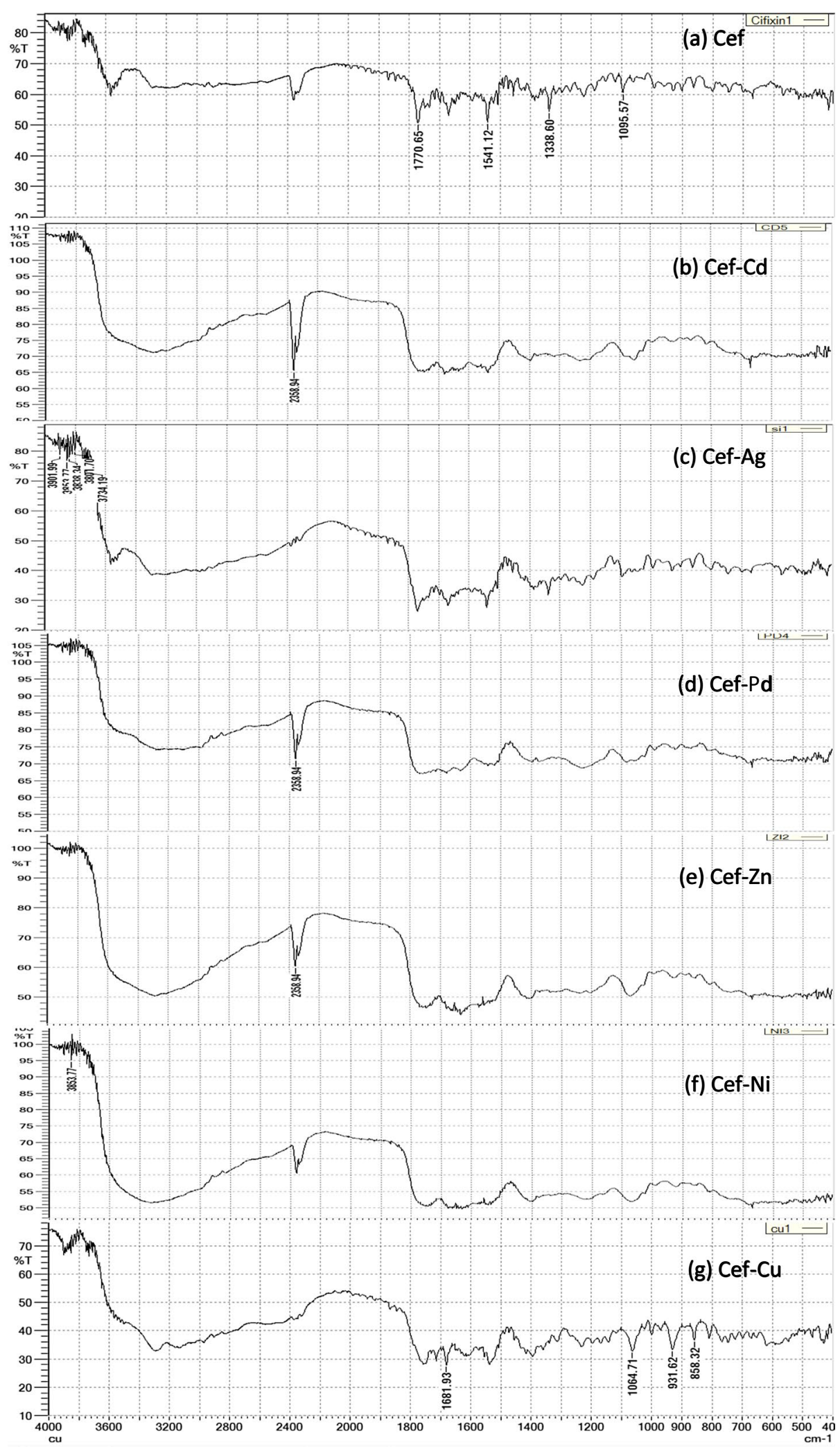

Fig. 4 FTIR spectrum of a Cef, b Cef-Cd, c Cef-Ag, d Cef-Pd, e Cef-Zn, f Cef-Ni and $\mathbf{g}$ Cef-Cu 
shifting to highest absorbance which might be associated with formation of complex with metal ion. The UV spectrum of cefixime in methanol found to be $289.4 \mathrm{~nm}$ which resembles to $\lambda_{\max }$ of cefixime compared with reference spectrum in the literature. The UV spectral data of the entire synthesized complexes showed the decrease in absorbance at $\lambda_{\max }$ of cefixime which might be due to binding of metal ion system.

\section{FTIR spectrophotometric analysis}

The structures of synthesized complexes were established by their IR spectra. Cyclic metal ion complexes with meropenem showed the IR absorptions given in Table 1. The FTIR spectra of all the compounds of cefixime were scanned in the region of $4000-400 \mathrm{~cm}^{-1}$. Metal ion complex with cefixime showed the IR absorptions characteristics of carbonyl $\mathrm{C}=\mathrm{O}\left(1700 \mathrm{~cm}^{-1}\right)$, aliphatic $\mathrm{C}-\mathrm{N}\left(1340 \mathrm{~cm}^{-1)}, \mathrm{N}-\mathrm{O}\left(1540 \mathrm{~cm}^{-1}\right), \mathrm{C}=\mathrm{C}(1670\right.$ $\left.1440 \mathrm{~cm}^{-1}\right), \mathrm{C}-\mathrm{S}\left(690-685 \mathrm{~cm}^{-1}\right)$. The FTIR spectra of all the compounds of meropenem were scanned in the region of $4000-700 \mathrm{~cm}^{-1}$. As shown in Fig. 3, the spectrum shows changes in wave number as compared to the standard drug which might be due to formation of metal ion complex [24]. As shown in Fig. 4, cyclic metal ion complex with cefixime showed the IR absorptions characteristics of carbonyl $\mathrm{C}=\mathrm{O}\left(1700 \mathrm{~cm}^{-1}\right)$, aliphatic $\mathrm{C}-\mathrm{N}\left(1340 \mathrm{~cm}^{-1}\right), \mathrm{N}-\mathrm{O}\left(1540 \mathrm{~cm}^{-1}\right), \mathrm{C}=\mathrm{C}(1670$ $\left.1440 \mathrm{~cm}^{-1}\right), C-S\left(690-685 \mathrm{~cm}^{-1}\right)$. From the above observations it was clear that the structure of cyclic drug metal complexes was confirmed [25].

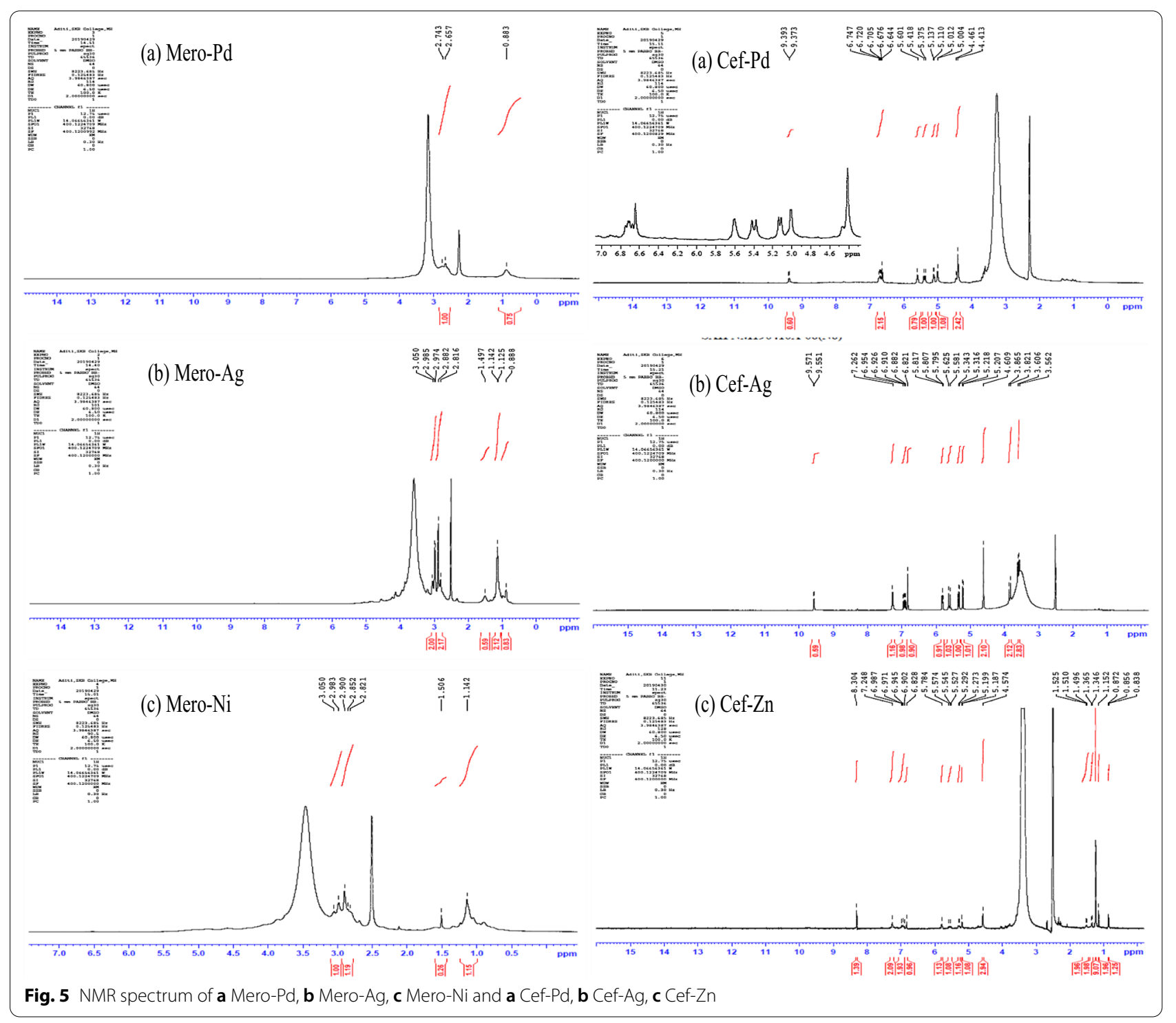


Table $2{ }^{1} \mathrm{H}-\mathrm{NMR}$ peaks of meropenem and cefixime metal ion complexes

\begin{tabular}{|c|c|c|}
\hline Sr. no & Compound name & H-NMR $\delta(p p m)$ in DMSO, nature of proton, coupling constant(J) \\
\hline 1 & Mero-Ag & $\begin{array}{l}1.12\left(3 \mathrm{H}, \mathrm{CH}-\mathrm{CH}_{3}\right), 1.14,1.49(2 \mathrm{H}, \mathrm{pyrol}), 2.81,2.88\left[6 \mathrm{H}, \mathrm{N}\left(\mathrm{CH}_{3}\right)_{2}\right] \\
2.97(1 \mathrm{H}, \text { chephem }), 3.05(1 \mathrm{H}, \text { pyrol })\end{array}$ \\
\hline 2 & Mero-Pd & $2.65,2.74\left[6 \mathrm{H}, \mathrm{N}\left(\mathrm{CH}_{3}\right)_{2}\right]$ \\
\hline 3 & Mero-Ni & $\begin{array}{l}1.14,1.5(2 \mathrm{H}, \text { pyrol }), 2.82,2.85\left[6 \mathrm{H}, \mathrm{N}\left(\mathrm{CH}_{3}\right)_{2}\right], 2.90(1 \mathrm{H}, \text { chephem }) \\
3.05(1 \mathrm{H}, \text { pyrol })\end{array}$ \\
\hline 4 & Cef-Pd & $\begin{array}{l}{ }^{1} \mathrm{H}-\mathrm{NMR}-6.987\left(2 \mathrm{H}, \mathrm{dd}, \mathrm{C}_{4} \mathrm{H}_{2} \mathrm{SN}\right), 4.461\left(2 \mathrm{H}, \mathrm{d}, \mathrm{C}_{4} \mathrm{H}_{2} \mathrm{SN}\right), 5.418\left(2 \mathrm{H}, \mathrm{d}, \mathrm{CH}_{2}=\mathrm{CH}_{2}\right), 5.601\left(2 \mathrm{H}, \mathrm{d},-\mathrm{CH}=\mathrm{CH}_{2}\right), 6.644\left(2 \mathrm{H}, \mathrm{d}, \mathrm{C}_{3} \mathrm{H}_{2} \mathrm{ON}\right) \text {, } \\
6.676\left(2 \mathrm{H}, \mathrm{d}, \mathrm{C}_{3} \mathrm{H}_{2} \mathrm{ON}\right), 5.110(1 \mathrm{H}, \mathrm{S},-\mathrm{COOH}), 9.373\left(1 \mathrm{H}, \mathrm{S}, \mathrm{C}_{3} \mathrm{HSNN}\right), 5.375\left(1 \mathrm{H}, \mathrm{S},-\mathrm{NH}_{2}\right)\end{array}$ \\
\hline 5 & Cef-Ag & $\begin{array}{l}{ }^{1} \mathrm{H}-\mathrm{NMR}-6.882\left(2 \mathrm{H}, \mathrm{dd},-\mathrm{CH}=\mathrm{CH}_{2}\right), 5.34\left(2 \mathrm{H}, \mathrm{dd},-\mathrm{CH}=\mathrm{CH}_{2}\right), 5.316\left(2 \mathrm{H}, \mathrm{d}, \mathrm{CH}=\mathrm{CH}_{2}\right), 4.603\left(2 \mathrm{H}, \mathrm{d},-\mathrm{C}_{4} \mathrm{H}_{2} \mathrm{SN}\right), 5.207\left(2 \mathrm{H}, \mathrm{d}, \mathrm{C}_{4} \mathrm{H}_{2} \mathrm{SN}\right), \\
5.581\left(2 \mathrm{H}, \mathrm{d}, \mathrm{C}_{3} \mathrm{H}_{2} \mathrm{ON}\right), 5.795\left(2 \mathrm{H}, \mathrm{d},-\mathrm{C}_{3} \mathrm{H}_{2} \mathrm{ON}\right), 7.262(1 \mathrm{H}, \mathrm{S},-\mathrm{COOH}), 9.571\left(1 \mathrm{H}, \mathrm{S}, \mathrm{C}_{4} \mathrm{H}_{2} \mathrm{SN}\right), 6.954\left(1 \mathrm{H}, \mathrm{S},-\mathrm{NH}_{2}\right)\end{array}$ \\
\hline 6 & Cef-Zn & $\begin{array}{l}{ }^{1} \mathrm{H}-\mathrm{NMR}-6.987\left(2 \mathrm{H}, \mathrm{dd},-\mathrm{CH}=\mathrm{CH}_{2}\right), 5.78\left(2 \mathrm{H}, \mathrm{dd},-\mathrm{CH}=\mathrm{CH}_{2}\right), 4.574\left(2 \mathrm{H}, \mathrm{d}, \mathrm{C}_{4} \mathrm{H}_{2} \mathrm{SN}\right), 5.187\left(2 \mathrm{H}, \mathrm{d},-\mathrm{C}_{4} \mathrm{H}_{2} \mathrm{SN}\right), 5.545\left(2 \mathrm{H}, \mathrm{d}, \mathrm{C}_{3} \mathrm{H}_{2} \mathrm{ON}\right) \text {, } \\
5.292\left(2 \mathrm{H}, \mathrm{d}, \mathrm{C}_{3} \mathrm{H}_{2} \mathrm{ON}\right), 5.199(1 \mathrm{H}, \mathrm{S},-\mathrm{COOH}), 9.304\left(1 \mathrm{H}, \mathrm{S}_{2} \mathrm{C}_{3} \mathrm{HSN}\right), 6.828\left(1 \mathrm{H}, \mathrm{S},-\mathrm{NH}_{2}\right)\end{array}$ \\
\hline
\end{tabular}

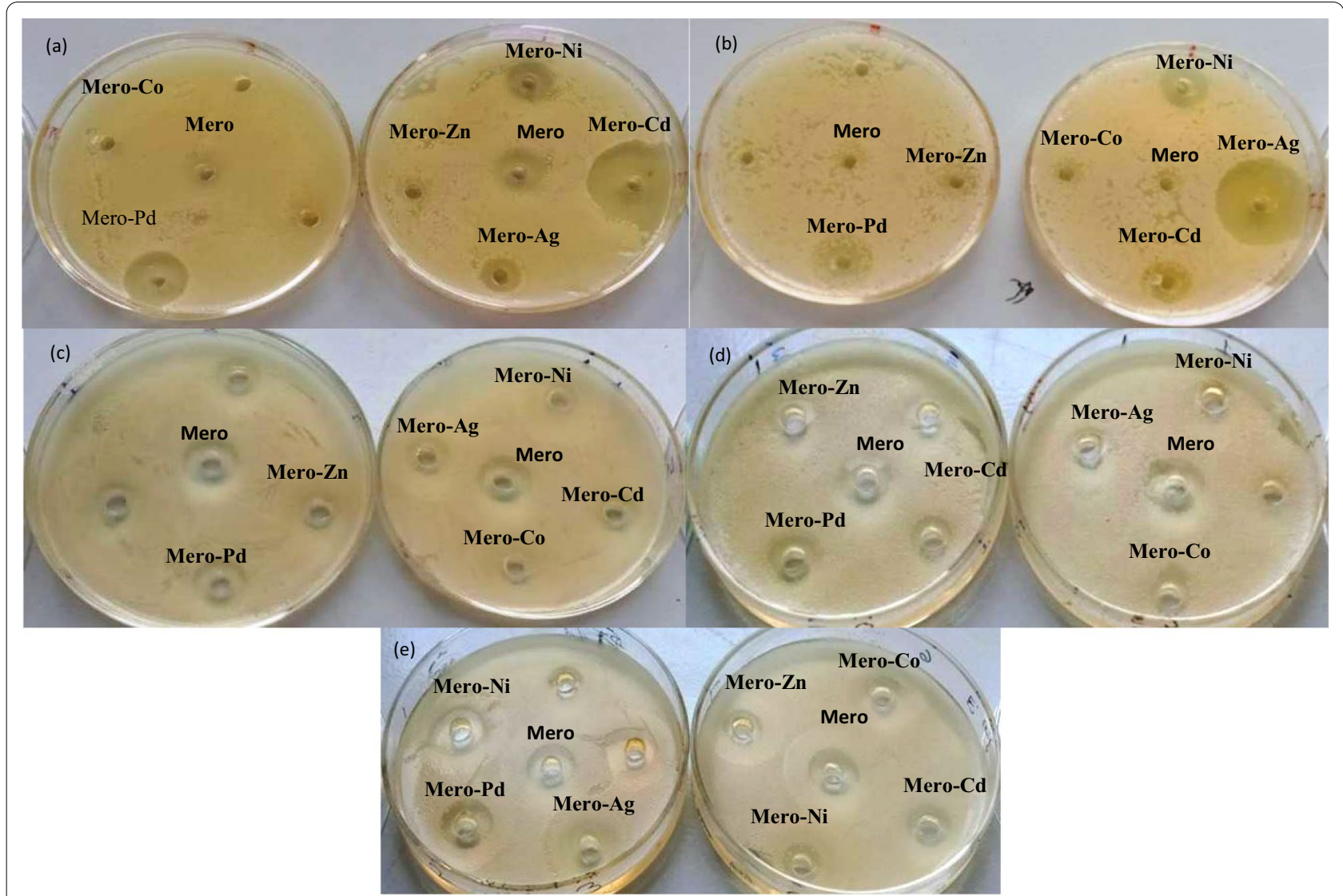

Fig. 6 Antibacterial activity by meropenem and its synthesized complexes against a P. aeruginosa, b K. pneumonia, c E. coli, d B. subtilis and e S. aureus

\section{NMR analysis}

The ${ }^{1} \mathrm{H}-\mathrm{NMR}$ of cyclic aliphatic compounds (cefixime) showed multiple at singlet due to $5.110(1 \mathrm{H}, \mathrm{S},-\mathrm{COOH})$, $9.373\left(1 \mathrm{H}, \mathrm{S}, \mathrm{C}_{3} \mathrm{HSN}\right), 5.375\left(1 \mathrm{H}, \mathrm{S},-\mathrm{NH}_{2}\right)$, doublet due to $\mathrm{C}_{4} \mathrm{H}_{2} \mathrm{SN}, 6.987,4.461,5.418,4.603,5.207,4.574,5.187$, and also, the doublet on 5.418, 6.882, 5.78. The change in the singlet appearing near 11 to 12 was missing in the cefixime complexes with palladium, silver and zinc which might be associated with confirmation of cefixime metal ion complexes. In case of meropenem, as shown in Fig. 5, the ${ }^{1} \mathrm{H}-\mathrm{NMR}$ of cyclic compounds showed multiple and singlet $\delta$ values are observed shifted as compared to standard meropenem drug. Some $\delta$ values are near to the standard drug values. The shifting of $\delta$ value is due to 


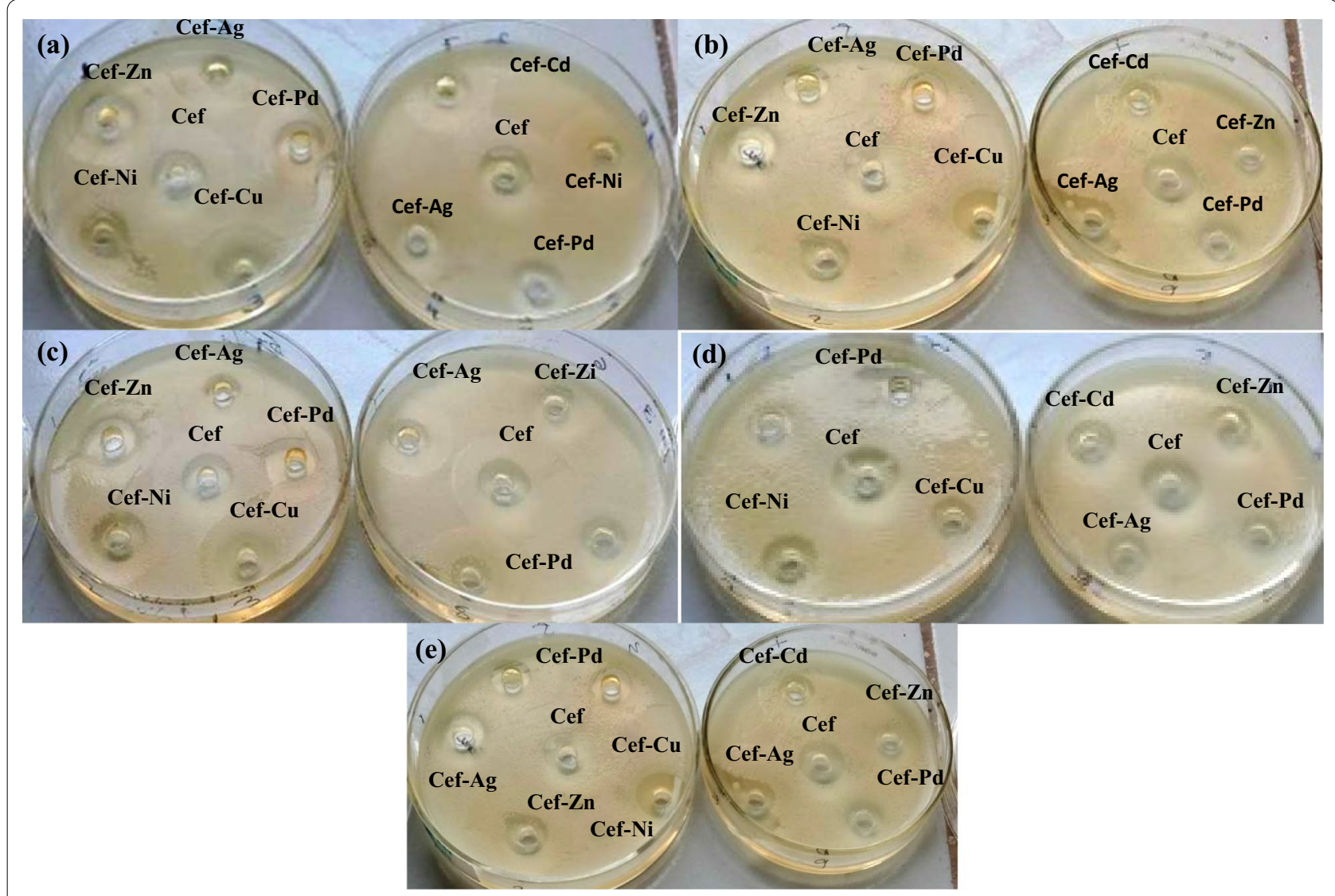

Fig. 7 Antibacterial activity by cefixime and its synthesized complexes a P. aeruginosa, b K. pneumonia, c E. coli, d B. subtilis and e S. aureus

metal ion complex with standard drug. The ${ }^{1} \mathrm{H}-\mathrm{NMR}$ is reported in Table 2 . All the synthesized compounds gave satisfactory data correlation with the assigned structure.

\section{Antibacterial activity}

The antimicrobial activity was performed for all the synthesized meropenem and cefixime metal ion complexes using cup plate method as shown in Figs. 6 and 7. The results showed that all the synthesized meropenem metal ion complexes possess moderate to good antibacterial activity, where in K. Pneumoniae and $P$. aeruginosa standard meropenem was not shown any activity, while meropenem-Cd and meropenem-Ni complexes showed good activity. All the meropenem metal ion complexes were found to be more active on the gram-negative bacteria than gram-positive bacteria out of which meropenem-Cd was more active against $E$. coli. It was also found that all the meropenem metal ion complexes possess more antibacterial activity as compared to meropenem. However, Mero-Cd, Mero-Ag and Mero-Pd were also found to be active against grampositive B. subtilis. The synthesized cefixime-metal ion complexes possess moderate to good antibacterial activity as compared to standard cefixime. The complexes were found to be more active on the gram-negative bacteria as compared to gram-positive bacteria. The inhibitory effect of the prepared complexes was significantly higher than their original ligand when they had been tested on the five types of bacteria [26-30].

\section{Minimum inhibitory concentration determination}

MIC appropriately calculated by broth dilution method is given in Table 3 . The MIC for E. coli of Mero-Cd complex was found to be $250 \mu \mathrm{g} / \mathrm{ml}$. Similarly, MIC for B. subtilis of Mero-Cd and Mero-Ag was found to be 200 and $300 \mu \mathrm{g} / \mathrm{ml}$, respectively. MIC for K. pneumoniae of Mero$\mathrm{Cd}$ and Mero-Ni was 100 and $250 \mu \mathrm{g} / \mathrm{ml}$. Also the MIC for $P$. aeruginosa of Mero-Cd, Mero-Pd, Mero-Ag and Mero-Ni was 150, 150, 250 and $250 \mu \mathrm{g} / \mathrm{ml}$, respectively. The MIC values of some complexes were found to be less than the meropenem, indicating that complexes have better antibacterial activity than plain drug.

The MIC for E. coli of Cef-Ag and Cef-Zn complexes was found to be $50 \mu \mathrm{g} / \mathrm{ml}$. MIC of $S$. aureus against 


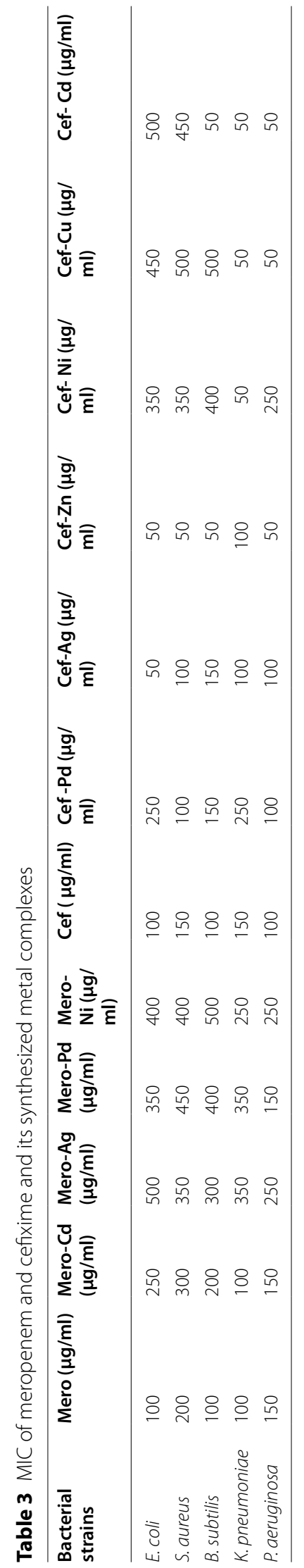


Cef-Ag, Cef-Pd and Cef-Zn was observed 100, 50 and $50 \mu \mathrm{g} / \mathrm{ml}$, respectively. Moreover, the MIC for B. subtilis against Cef-Ag, Cef-Pd, Cef-Zn and Cef-Cd was found to be 150 and $50 \mu \mathrm{g} / \mathrm{ml}$, respectively. Similarly, the MIC for K. pneumonia of Cef with $\mathrm{Pd}, \mathrm{Ag}, \mathrm{Zn}, \mathrm{Ni}, \mathrm{Cu}, \mathrm{Cd}$ and MIC for P. aeruginosa of complexes of Cef with $\mathrm{Pd}, \mathrm{Ag}$, $\mathrm{Zn}, \mathrm{Cu}$ and $\mathrm{Cd}$ was found to be less than cefixime, indicating better antibacterial activity than plain cefixime.

\section{Discussion}

The present paper emphasizes on synthesis and evaluation of meropenem and cefixime metal ions complexes for their antibacterial activity against normal and resistant strains. As per literature review, the proficient use of meropenem and cefixime as a higher antibacterial drug by practitioners and reported antibacterial activities of the metal ions motivated to synthesize drug metal ion complexes and its antibacterial activities. Silver, palladium, zinc, cadmium, nickel and copper metal ions were selected as no previous paper was available for these metal ions with meropenem and cefixime. The synthesis process was performed for meropenem and cefixime with all the metal ions as per the reference [13-18]. Synthesized complexes were confirmed by evaluating the organoleptic parameters such as the initial nature of meropenem and cefixime was white and amorphous in nature, whereas the synthesized complexes of meropenem and cefixime with metal ions change in appearance which might be associated with formation of complex with the metal ion. The prepared complexes have been shown different colors than the initial giving primary indication of formation of complex. Furthermore, the solubility of complexes was found to be more in 5\% sodium hydroxide and conc. sulfuric acid, whereas the solubility in water, $5 \%$ hydrochloric acid and ether was observed partial or insoluble, indicating binding of metal ion with drug may decrease solubility in water.

Moreover, the UV spectral data of the entire synthesized metal ion complexes have shown decrease in absorbance at $\lambda_{\max }$ of meropenem and cefixime which might be due to binding of metal ion with the respective drug, whereas in some complexes a slight shift in $\lambda_{\max }$ was observed. As per literature review, any change in the absorbance at $\lambda_{\max }$ of drug indicates the binding of some group or metal ion. Further for structural confirmation FTIR studies were carried out which indicated that the functional groups of meropenem and cefixime were retained in the synthesized metal ion complexes and shown peaks associated with metal ions confirm the structure of synthesized complexes [22-25].

${ }^{1} \mathrm{H}-\mathrm{NMR}$ analysis confirms the binding of metal ions on meropenem and cefixime. The change in the singlet appearing near 11 to 12 was missing in the cefixime complexes with palladium, silver and zinc which might be associated with confirmation of cefixime metal ion complexes. In case of meropenem, the ${ }^{1} \mathrm{H}-\mathrm{NMR}$ of cyclic compounds showed multiple and singlet $\delta$ values are observed shifted as compared to standard meropenem drug. Some $\delta$ values are near to the standard drug values. All the synthesized compounds gave satisfactory data correlation with the assigned structure.

The results of antibacterial activity showed that all the synthesized complexes possess moderate to good antibacterial activity than a standard drug. The complexes were found to be more active on the gram-negative bacteria as compared to gram-positive bacteria. The inhibitory effect of the prepared complexes was significantly higher than their original ligand when they had been tested on the five types of bacteria, whereas in $K$. Pneumoniae and P. aeruginosa standard meropenem was not shown any activity, while meropenem-Cd and meropenem-Ni complexes showed good activity. All the meropenem metal ion complexes were found to be more active on the gram-negative bacteria than grampositive bacteria out of which meropenem-Cd was more active against $E$. coli. It was also found that all the meropenem metal ion complexes possess more antibacterial activity as compared to meropenem. However, Mero-Cd, Mero-Ag and Mero-Pd were also found to be active against gram-positive $B$. subtilis [26, 27]. MIC for meropenem and cefixime metal ion complexes was appropriately calculated by broth dilution method. The MIC values of some complexes specifically Mero-Cd, Mero-Pd, Cef-Ag, Cef-Cd and Cef-Zn against gramnegative bacteria were found to be less than the meropenem and cefixime, indicating that the complexes have better antibacterial activity than plain drug [28-30].

\section{Conclusions}

Metal ion complexes for meropenem and cefixime were confirmed by UV, FTIR and NMR analysis. All the synthesized metal ion complexes exhibited good antimicrobial activity, whereas Mero-Cd, Mero-Ag, Mero-Pd, Mero-Ni, Cef-Pd, Cef-Zn and Cef-Cd complexes have reflected notable antibacterial activity. Furthermore, they also have strong antibacterial action against $K$. Pneumoniae and P. aeruginosa in comparison with standard drugs. These complexes can be thus implied for further development of antibacterial molecules for resistant species.

\footnotetext{
Abbreviation

AMC: Antibiotic-metal complexes; B. subtilis: Bacillus subtilis; E. coli: Escherichia coli; FTIR: Fourier's Transform Infrared Spectrophotometry; K. pneu-
} moniae: Klebsiella pneumoniae; MDR: Multidrug Resistance; MIC: Minimum 
Inhibitory Concentration; NMR: Nuclear Magnetic Resonance; P. aeruginosa: Pseudomonas aeruginosa; S. aureus: Staphylococcus aureus; UV: UV-Visible Spectrophotometry.

\section{Acknowledgements}

Not applicable.

\section{Authors' contributions}

RL contributed in planning of the synthesis procedures for all antibacterial metal ion. He performed extensive literature survey and compiled the content. NR contributed in preparation of and practical work carried out at laboratory. KG contributed in analyzing the analytical reports of all the synthesized antibacterial metal ion complexes. MU contributed in outlining and performing the work in laboratories. NK contributed in performing antibacterial studies and checking of manuscript and correction of grammatical mistake. All authors read and approved the final manuscript.

\section{Funding}

Not applicable.

\section{Availability of data and materials}

Meropenem trihydrate was gifted by Aurobindo Pharma Limited, and cefixime trihydrate was gifted by Zim Laboratories. Metal salts cadmium chloride, silver chloride, palladium chloride, zinc chloride, nickel chloride and cobalt chloride ( $\mathrm{CdCl}_{2}(\mathrm{II}), \mathrm{AgCl}_{2}(\mathrm{II}), \mathrm{PdCl}_{2}(\mathrm{II}), \mathrm{ZnCl}_{2}(\mathrm{II}), \mathrm{NiCl}_{2}(\mathrm{II})$ and $\left.\mathrm{CoCl}_{2}(\mathrm{II})\right)$, other solvents and reagent of analytical grade were purchased from Lobachemie and Merck PVT LTD, FTIR and ${ }^{1} \mathrm{H}$-NMR spectra recorded on Prestige-21 FTIR instrument were FTIR 8004 s. ${ }^{1} \mathrm{H}$ - NMR instruments were Bruker AMX $400 \mathrm{MHz}$. Chemical shifts were reported in ppm using tetramethylsilane (TMS) as an internal standard. UV-visible spectra recorded on Jasco v-63 spectrometer.

\section{Declarations}

Ethics approval and consent to participate

Not applicable.

\section{Consent for publication}

Not applicable.

\section{Competing interests}

The authors declare that they have no competing interests.

\section{Author details}

${ }^{1}$ Smt. Kishoritai Bhoyar College of Pharmacy, Kamptee, Nagpur, Maharashtra 441002 , India. ${ }^{2}$ Division of Neuroscience, Department of Pharmacology, Government College of Pharmacy, Amravati 444603, India.

Received: 8 July 2021 Accepted: 13 November 2021 Published online: 04 December 2021

\section{References}

1. Regiel-Futyra A, Da browski JM, Mazuryk O, Spiewak K, Kyzioł A, Pucelik B, Brindell M, Stochel G (2017) Bioinorganic antimicrobial strategies in the resistance era. Coord Chem Rev 351:76117. https://doi.org/10.1016/j.ccr. 2017.05.005

2. Ahmad S, Isab AA, Ali S, Al-Arfaj AR (2006) Perspectives in bioinorganic chemistry of some metal based therapeutic agents. Polyhedron 25(7):1633-1645. https://doi.org/10.1016/j.poly.2005.11.004

3. Tahir S, Mahmood T, Dastgir F, Haq I, Waseem A, Rashid U (2019) Design, synthesis and anti-bacterial studies of piperazine derivatives against drug resistant bacteria. Eur J Med Chem 166:224-231. https://doi.org/10. 1016/j.ejmech.2019.01.062

4. Singh DP, Malik V, Kumar R (2009) Synthesis and characterization of biologically active 10-membered tetraazamacrocyclic complexes of $\mathrm{Cr}(\mathrm{III})$, Mn(III), and Fe(III). Int J Inorg Chem Article ID 824561:4. https://doi.org/10. $1155 / 2009 / 824561$

5. Sankaranarayana Pillai M, Pushpa Latha S (2012) Designing of some novel metallo antibiotics tuning biochemical behaviour towards therapeutics: synthesis, characterisation and pharmacological studies of metal complexes of cefixime. J Saudi Chem Soc. https://doi.org/10.1016/j.jscs.2012. 09.004

6. Ramotowska S, Wysocka M, Brzeski J, Chylewska A, Makowski M (2020) A comprehensive approach to the analysis of antibiotic-metal complexes. TrAC Trends Anal Chem 123:115771. https://doi.org/10.1016/j.trac.2019. 115771

7. Arayne SM, Sultana N, Shamim S, Naz A (2014) Synthesis characterization and antimicrobial activities of azithromycin metal complexes. Mod Chem appl 2:3. https://doi.org/10.4172/2329-6798.1000133

8. Santos AF, Brotto DF, Favarin LRV, Cabeza NA, Andrade GR, Batistote M, Cavalheiro AA, Neves A, Rodrigues DCM, Anjos AD (2014) Study of the antimicrobial activity of metal complexes and their ligands through bioassays applied to plant extracts. Rev Bras 24(3):309-315. https://doi. org/10.1016/j.bjp.2014.07.008

9. Kostova I (2010) Metal-containing drugs and novel coordination complexes in therapeutic anticancer applications-part II. Anticancer Agents Med Chem 10(5):352-353. https://doi.org/10.2174/187152061100905 0352

10. Cheesman MJ, Ilanko A, Blonk B, Cock IE (2017) Developing new antimicrobial therapies: are synergistic combinations of plant extracts/ compounds with conventional antibiotics the solution? Pharmacogn Rev 11(22):57-72. https://doi.org/10.4103/phrev.phrev_21_17

11. Takeuchi Y, Inoue T, Sunagawa M (1993) Studies on the structures of meropenem(SM-7338) and it's primary metabolite. J Antibiot 46(5):827832. https://doi.org/10.7164/antibiotics.46.827

12. Danish M (2015) Metal complexes and organotin(IV) compounds of cefixime and their biological study. Med Chem. https://doi.org/10.4172/ 2161-0444.1000288

13. Morrelli LP (1975) Analytical profile of drug substances, vol 4. Academic Press, p 21

14. Arif M, Qurashi MR, Shad MA (2011) Metal-based antibacterial agents: synthesis, characterization, and in vitro biological evaluation of cefiximederived Schiff bases and their complexes with Zn(II), Cu(II), Ni(II), and Co(II)M. J Coord Chem 64(11):1914-1930. https://doi.org/10.1080/00958 972.2011.582867

15. Sutton BJ, Artymiuk PJ, Cordero-Borboa AE, Little C, Phillips DC, Waley SG (1987) An X-ray-crystallographic study of beta-lactamase II from Bacillus cereus at $0.35 \mathrm{~nm}$ resolution. Biochem J 248:181-188. https://doi.org/10. 1042/bj2480181

16. And YS, Kurt M (2003) Vibrational spectroscopic studies of metal (II) halide benzimidazole. J Mol Struct 650:181-190. https://doi.org/10.1016/S00222860(03)00153-4

17. Waziri I, Ndahi NP, Paul BB (2013) Synthesis, physicochemical and antimicrobial studies of Co(II), Zn(II) and Fe(III) mixed antibiotics metal complexes. J Chem Pharm Res 5:84-89

18. Yanick Gaëlle DS, Yufanyi DM, Jagan R, Darren Bradshaw MOA (2016) Synthesis, characterization and antimicrobial properties of cobalt(II) and cobalt(III) complexes derived from 1,10-phenanthroline with nitrate and azide co-ligands. Cogent Chem 2:1. https://doi.org/10.1080/23312009. 2016.1253201

19. Anacona JR, Estacio J (2006) Synthesis and antibacterial activity of cefixime metal complexes. Transition Met Chem 31:227-231. https://doi. org/10.1007/s11243-005-6360-9

20. Kokare C (2010) Pharmaceutical microbiology, experiments and techniques, 3rd edn. Career Publications, pp 147-148

21. Andrews JM (2001) Determination of minimum inhibitory concentrations. J Antimicrob Chemother 1:5-16. https://doi.org/10.1093/jac/48. suppl_1.5

22. Galdes A, Hill HA, Baldwin GS, Waley SG, Abraham EP (1980) The $1 \mathrm{H}$ nuclear-magnetic-resonance spectroscopy of cobalt(II)-beta-lactamase II. Biochem J 187(3):789-795. https://doi.org/10.1042/bj1870789

23. Verma S, Shrivastva S, Rani P (2012) Synthesis and spectroscopic studies of mixed ligand complexes of transition and inner transition metals with a substituted benzimidazole derivative and RNA bases. J Chem Pharm Res 4(1):693-699

24. Sharma YR (1980) Elementary organic spectroscopy, revised. S. Chand Publication, p 11

25. El-Asmy AA, Khalifa ME, Hassania MM (2004) Synthesis and characterization of transition metal complexes containing oxime, amido and thiamido groups. India J Chem 43A:92-97 
26. Abdulsada AH (2017) Synthesis characterization and antibacterial evaluation of cephradine and ceftriaxone Schiffbase copper complexes. J Curr Chem Pharm Sci 7(1):101

27. Auda SH, Knütter I, Bretschneider B, Brandsch M, Mrestani Y, Große C, Neubert RH (2009) Effect of different metal ions on the biological properties of cefadroxil. Pharm (Basel) 2(3):184-193. https://doi.org/10.3390/ ph2030184

28. Tomova I, Stoilova-Disheva M, Lazarkevich I, Vasileva-Tonkova E (2015) Antimicrobial activity and resistance to heavy metals and antibiotics of heterotrophic bacteria isolated from sediment and soil samples collected from two Antarctic islands. Front Life Sci 8(4):348-357. https://doi.org/10. 1080/21553769.2015.1044130

29. Yayan J, Ghebremedhin B, Rasche K (2015) Antibiotic resistance of pseudomonas aeruginosa in pneumonia at a Single University Hospital Center in Germany over a 10-year period. PLoS ONE 10(10):0139836. https://doi. org/10.1371/journal.pone.0139836

30. Estrada-Garcia T, Hodges K, Hecht GA, Tarr PI (2013) Escherichia coli. In: Food science and technology, foodborne infections and intoxications, 4th edn. Academic Press, pp 129-164. https://doi.org/10.1016/B978-0-12416041-5.00008-1

\section{Publisher's Note}

Springer Nature remains neutral with regard to jurisdictional claims in published maps and institutional affiliations.

\section{Submit your manuscript to a SpringerOpen ${ }^{\circ}$ journal and benefit from:}

- Convenient online submission

- Rigorous peer review

- Open access: articles freely available online

- High visibility within the field

- Retaining the copyright to your article

Submit your next manuscript at $\gg$ springeropen.com 